\title{
Pengembangan Media Pembelajaran Berbasis Lectora Inspire Pada Materi Konsep Badan Usaha Dalam Perekonomian Indonesia Untuk Meningkatkan Kemampuan Berpikir Kritis Siswa
}

\author{
Faridathul Khasanah \\ Program Studi Pendidikan Ekonomi, Fakultas Ekonomi, Universtas Negeri Surabaya \\ e-mail : faridathul.khasanah@mhs.unesa.ac.id \\ Albrian Fiky Prakoso \\ Program Studi Pendidikan Ekonomi, Fakultas Ekonomi, Universtas Negeri Surabaya \\ e-mail : albrianprakoso@unesa.ac.id
}

\begin{abstract}
Abstrak
Seringnya penggunaan media power point dan papan tulis dalam proses pembelajaran serta belum adanya variasi media pembelajaran yang lebih interaktif membuat peserta didik cenderung merasa bosan dalam pembelajaran di kelas dan kemampuan berpikir kritis siswa juga masih tergolohn rendah, hal tersebut diketahui dari mereka ketika disajikan soal berkemampuan tinggi masih bingung dan mencoba melihat jawaban teman. Penelitian pengembangan atau Research and Development (R\&D) ini bertujuan untuk mendiskripsikan kelayakan media serta efektifitas media berbasis Lectora Inspire. Model yang digunakan adalah 4D Models menurut Thiagaradjan yang terdiri dari 4 tahapan yaitu Define (Pendefinisian), Design (Perancangan), Develop (Pengembangan) dan Disseminate (Penyebaran) yang dilakukan secara terbatas. Hasil penelitian diperoleh melalui validasi ahli evaluasi dan ahli media, serta analisis butir soal. Hasil validasi oleh ahli evaluasi menunjukkan bahwa butir soal yang disajikan pada media pembelajaran berbasis Lectora Inspire telah sesuai dengan indikator penilaian ahli evaluasi, persentase rata-rata hasil validasi oleh ahli media sebesar $92 \%$ menunjukkan dalam kategori sangat layak, kemudian pada analisis butir soal terdapat 14 dari 20 soal yang dikatakan valid setelah diujicobakan serta pada efektifitas media adanya perbedaan nilai pretest dan posttest dan $85 \%$ siswa mendapat nilai diatas $\geq 75$. Sehingga dapat disimpulkan bahwa media pembelajaran berbasis Lectora Inspire sebagai media pembelajaran sangat layak digunakan sebagai alternatif media pembelajaran dikelas untuk membantu dalam proses pembelajaran.
\end{abstract}

Kata Kunci: Penelitian dan Pengembangan, Media pembelajaran, Lectora Inspire.

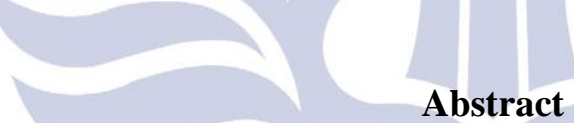

The frequent use of power point and blackboard media in the learning process and the absence of more interactive learning media variations make students tend to feel bored in classroom learning and students' critical thinking skills are still low, it is known to them when presented with high-ability questions still confused and trying to see a friend's answer. The research and development (R \& D) research aims to describe the feasibility of the media and the effectiveness of the Lectora Inspire-based media. The model used is 4D Models according to Thiagaradjan which consists of 4 stages, namely Define, Design, Develop and Disseminate which is done in a limited manner. The results of the study were obtained through validation of expert evaluation and media experts, as well as item analysis. The results of the validation by the evaluation expert showed that the items presented on the Lectora Inspire based learning media were in accordance with the expert evaluation evaluation indicators, the average percentage of the validation results by media experts was $92 \%$ indicating that in the category there were 14 from 20 questions that were said to be valid after being tested and on media effectiveness there were differences in the values of pretest and posttest and $85 \%$ of students scored above siswa $\geq 75$. So it can be concluded that the Lectora Inspire based learning media as a learning media is very feasible to use as an alternative learning media in the classroom to assist in the learning process.

Keywords: Research and Development, Learning Media, Lectora Inspire.

\section{PENDAHULUAN}

Pendidikan merupakan salah satu faktor yang sangat penting dalam mempengaruhi kualitas sumber daya manusia, sehingga melalui pendidikan diharapkan dapat mencetak generasi penerus yang berkualitas serta dapat berdaya saing tinggi. Pendidikan telah menjadi sebuah kebutuhan yang sangat penting, karena pada hakekatnya pendidikan merupakan usaha untuk membimbing kemampuan invidu dalam mengembangkan minat dan bakat peserta didik. Saat ini dunia pendidikan semakin berkembang, berbagai macam inovasi dilakukan agar kualitas dan kuantitas pendidikan dapat meningkat. Salah satunya yaitu melalui pembaharian kurikulum. 
Berdasarkan kurikulum yang diterapkan di Indonesia saat ini yaitu kurikulum 2013 revisi, dimana dalam kurikulum 2013 revisi ini merupakan lebih berorientasi pada pembentukan karakter siswa, dalam penerapannya lebih mendidik siswa untuk melakukan observasi/pengamatan dan bernalar hal tersebut agar siswa lebih mudah memahami materi yang ia dapatkan serta nantinya akan mendorong siswa berpikir secara kritis, analitis dan tepat dalam mengidentifikasi, memahami dan memecahkan masalah (Morelent, 2015)

Menurut Choy (2009) berpikir kritis merupakan proses yang memerlukan pengetahuan tingkat tinggi dalam proses informasi. Sehingga kemampuan berpikir kritis dalam kurikulum saat ini perlu dikembangkan. Namun pada kenyataannya, kemampuan berpikir kritis peserta didik di Indonesia saat ini masih tergolong rendah. Hal ini diketahui dari hasil Programme for International Student Asssesment (PISA) 2015, skor literasi sains Indonesia adalah 403 dengan peringkat 62 dari 70 negara yang berpartisipasi (OECD, 2015). Dimana peserta didik indonesia rata-rata hanya mampu menjawab soal level kognitif 1 sampai level 3.

Selain itu, dalam Permendikbud Tahun 2016 No. 22, bahwa salah satu prinsip pembelajaran yaitu pemanfaatan teknologi informasi dan komunikasi untuk meningkatkan efisiensi dan efektivitas pembelajaran, namun pada kenyaatan yang terjadi masih banyak sekolah yang belum memanfaatkan dan menerapkan teknologi yang ada, contohnya dalam proses pembelajaran guru seringkali menggunakan pembelajaran satu arah yang kemudian siswa diberi tugas yang ada di LKS maupun buku BSE yang telah disediakan oleh sekolah.

Berdasarkan observasi dan wawancara dengan salah satu guru ekonomi di SMA Negeri 1 Kutorejo, dalam proses pembelajaran khususnya dalam kelas X IIS, guru sudah menggunakan teknologi berupa LCD, proyektor dan laptop. Dalam penyampaian materi pelajaran guru menggunakan media pembelajaran berupa power point dan papan tulis, dalam penyampaian materi guru mengambil materi dari buku BSE yang disediakan oleh sekolah untuk siswa, namun penggunaan power point ini hanya sebatas penyampaian materi, belum sampai dengan latihan soal. Sehingga seringnya penggunaan media power point ini membuat peserta didik cenderung bosan dan konsentrasi juga cenderung turun, hal tersebut berdampak pada pengerjaan soal yang dilakukan secara konvensional,hal tersebut akan membuat peserta didik tidak sungguh-sungguh serta melihat hasil jawaban dari temannya.

Dari hasil observasi dan wawancara diatas, dapat disimpulkan bahwa perlu adanya media pembelajaran yang dapat membantu proses pembelajaran dikelas dan dapat digunakan sebagai media belajar peserta didik secara mandiri dalam mengerjakan latihan soal yang mengacu pada soal kemampuan berpikir kritis. Dengan begitu peserta didik dapat memanfaatkan teknologi yang ada dengan positif. Sehingga peneliti melakukan penelitian pengembangan yang berjudul "Pengembangan Media Pembelajaran berbasis Lectora Inspire pada materi konsep badan usaha dalam perekonomian Indonesia untuk meningkatkan kemampuan berpikir kritis siswa"

Tujuan dilakukannya penelitian ini yaitu untuk mendiskripsikan kelayakan media pembelajaran digunakan dalam proses pembelajaran pada materi konsep badan usaha dalam perekonomian Indonesia dan untuk mendiskripsikan efektivitas media pembelajaran berbasis Lectora Inspire pada materi konsep badan usaha dalam perekonomian Indonesia untuk meningkatkan kemampuan berpikir kritis siswa

Menurut Heinich (dalam Arsyad, 2014) media sebagai pengantar informasi diantaranya sumben dan penerima dapat dijadikan sebuah media komunikasi diantaranya televisi, foto, radio, dan bahan cetakan lainnya. Media pembelajaran yang terdapat pesan dan informasi dan mengandung maksud dari sebuah pengajaran. Keberhasilan proses pembelajaran juga dipengaruhi dengan media yang digunakan dalam proses pembelajaran. Seperti yang dikatakan oleh Daryanto (2016) Pemilihan media disesuiakan dengan tujuan, materi, serta kemampuan karakteristik peserta didik, akan menunjang efisiensi dan efektifitas proses dan hasil pembelajaran.

Menurut Daryanto (2016, p. 69) Multimedia Interaktif adalah suatu perangkat yang dilengkapi dengan alat pengontrol untuk mempermudah bagi pengguna (user) serta pengguna juga dapat memilih dan mengoperasikan apa yang dikehendaki untuk proses berikutnya. Contoh multimedia interaktif adalah pembelajaran interaktif, aplikasi games, dan lain-lain

Pengembangan media pembelajaran ini memanfaatkan tekonologi yang ada yaitu dengan menggunakn software Lectora Inspire yang merupakan salah satu software untuk membuat media pembelajaran yang interaktif. Serta Lectora Inspire ini memiliki beberapak keunggulan yaitu dapat digunakan untuk membuat website, knten e-learning interaktif, template yang cukup lengkap, tidak memerlukan Bahasa pemrograman yang ahli serta dilengkapi membuat soal dengan mudah. Sehingga pengembangan media ini dapat membuat proses pembelajaran yang lebih menarik dan dapat meningkat kemampuan berpikir kritis siswa.

Kriteria kelayakan media menurut Walker dan Hess (dalam Arsyad, 2014) meliputi tiga aspek yaitu kualitas isi dan tujuan, kualitas instruksional serta kualitas teknis. Untuk menentukan kuaitas isi pada media menggunakan validitas untuk mengukur sejauh mana tes telah mengukur 
apa yang diukur. Validitas terbagi menjadi dua yaitu validitas logis dan empiris (Arikunto, 2013). Validitas logis sama dengan analisis kualitatif, sedangkan validitas empiris sama dengan analisis kuantitatif yaitu melalui analisis butir soal.

Menurut Amri (2015) berpikir kritis adalah suatu aktivitas pengetahuan yang berkaitan dengan penalaran berpikir seseorang. Belajar untuk berpikir kritis berarti menggunakan proses-proses mental, seperti memperhatikan, mengkategorikan, seleksi dan menilai/memutuskan. Dalam hal ini peneliti menggunakan tahap berpikir kritis menurut Abdullah \& Suhartini (2017) yang memiliki 6 variabel, yaitu menginterpretasikan, menganalisis, mengevaluasi, menarik kesimpulan, penjelasan dan kemandirian.

Efektivitas media merupakan suatu ujuran untuk mengetahui tingkat keberhasilan dari suatu proses pembelajaran (Muhli, 2011). Kriteria efektivitas yang digunakan dalam penelitian ini yaitu melalui ketuntas belajar dimana sekurang-kurangnya $75 \%$ dari jumlah siswa mendapat nilai diatas KKM, media diakatakan efektif apabila adanya perbedaan nilai pre-test dan posttest dan media pembelajaran dikatakan efektif apabila dapat meningkatkan minatbelajar siswa setelah menggunakan media ini untuk mendapatkan hasil yang lebih baik lagi.

Berdasarkan peneliti yang telah mengembangkan media pembelaaran berbasis Lectora Inspire menyatakan bahwa media tersebut layak digunakan sebagai media pembelajaran dikelas seperti penelitian Marta, Simorangkir, Kariani, \& Sembiring (2018) dimana kelayakan media yang di validasi oleh ahli media sebesar $87,5 \%$ dengan kategori sangat layak serta peningkatan hasil belajar dengan rata-rata gain score sebesar 0,7 dengan kategori tinggi, selain itu dari penelitian Sari \& Sugiyarto (2015) diketahui bahwa media pembelajaran berbasis Lectora Inspire dapat meningkat kemampuan berpikir kritis siswa.

\section{METODE}

Jenis penelitian yang digunakan adalah penelitian pengembangan atau Research and Devepment (R\&D) dengan model pengembangan 4-D menurut Thiagaradjan, Semmel, dan Semmel (1947) yang melalui 4 proses tahapan pengembangan yaitu pendefinisian (Define), perancangan (Design), pengembangan (Develop), dan penyebaran (Disseminate).
Skema penelitian model 4-D adalah sebagai berikut : Gambar 1 Model 4-D

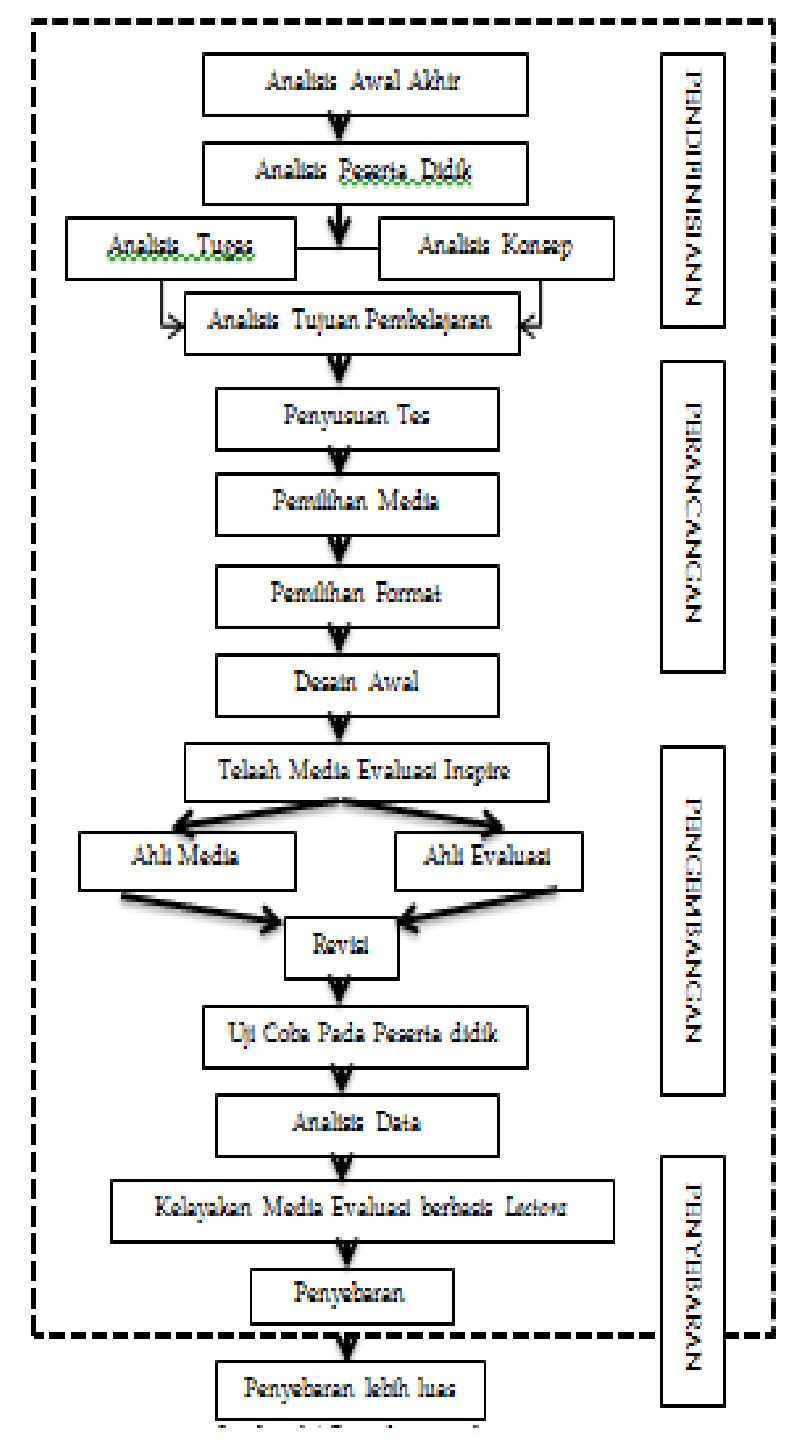

Sumber : Trianto (2012)

Tahapan pertama pada model pengembangan 4-D adalah tahap pendefinisian (Define). Pada tahap pendefinisian terdapat lima tahap, yaitu : (a) Analisis ujung depan; (b) Analisis peserta didik; (c) Analisis Tugas; (d) Analisis konsep ; dan (e) Analisis tujuan pembelajaran. Tahap kedua yaitu perancangan yang bertujuan untuk membuat draft desain media yang diinginkan. Tahap ketiga yaitu pengembangan yang bertujuan untuk menghasilkan media yang telah di telaah dan di validasi sehingga layak digunakan. Tahap keempat yaitu penyebaran dimana pada tahap ini dilakukan penyebaran secara terbatas.

Desain uji coba pada penelitian ini menggunakan PreExperimental Design dengan desain One-Group PretestPosttest. Menurut (Sugiyono, 2016) desain One-Group Prestest-Posttest merupakan model uji coba yang diberikan Pre-test sebelum Perlakuan dan Post-test 
setelah perlakuan untuk melihat hasil kognitis siswa yang lebih akurat.

Gambar 2 Desain Uji Coba

$$
0_{1}-\mathrm{X}-0_{2}
$$

Keterangan :

$\mathrm{O}_{1}$ : Nilai Pre-test

$\mathrm{X}:$ Treatment

$\mathrm{O}_{2}:$ Nilai Post-test

(sumber : diadaptasi dari Sugiyono, 2016)

Subjek uji coba penelitian ini adalah siswa kelas $\mathrm{X}$ IPS di SMAN 1 Kutorejo sebanyak 20 peserta didik sesuai pendapat (Sadiman, 2014). Instrumen penelitian menggunakan angket penilaian ahli evaluasi untuk mengetahui kelayakan butir soal, ahli media untuk mengetahui kelayakan media pembelajaran tersebut serta analisis butir soal untuk mengetahui kelayakan butir soal yang akan digunakan sebagai bahan evaluasi belajar siswa. Teknik pengumpulan data menggunakan data kuantitatif. Lembar telaah ahli evaluasi dianalisis kemudian divalidasi oleh ahli evaluasi dengan interpretasi kualitatif. Pada telaah media dianalisis kemudian divalidasi dengan interpretasi penilaian skor pada Skala Likert serta analisis butir soal yang meliputi taraf kesukaran, daya pembeda, validitas dan reliabilitas.

Berikut interpretasi penilaian angket instrumen penelitian menggunakan Skala Likert :

Tabel 1 Skala Likert

\begin{tabular}{cc}
\hline Penilaian & Skala \\
\hline $0 \%-20 \%$ & Sangat tidak layak \\
\hline $21 \%-41 \%$ & Tidak layak \\
\hline $41 \%-60 \%$ & Cukup layak \\
\hline $61 \%-80 \%$ & Layak \\
\hline $81 \%-100 \%$ & Sangat layak \\
Sumber : Riduwan (2016) & C S
\end{tabular}

\section{HASIL DAN PEMBAHASAN}

Penelitian yang dilakukan bertujuan untuk menghasilkan suatu media pembelajaran berbasis Lectora Inspire yang layak digunakan sebagai media pembelajaran pada konsep badan usaha dalam perekonomian Indonesia untuk kelas X IPS semester ganjil. Kelayakan media yang dikembangkan ditinjau dari beberapa aspek yaitu dari kelayakan media oleh ahli evaluasi dan ahli media serta analisis butir soal, sedangkan efektifitas media diperoleh dari nilai pretest dan posttest

\section{Kelayakan Media}

Kelayakan media pembelajaran berbasis Lectora Inspire divalidasi secara konstruk dan empiris. Pada validasi konstruk yaitu validasi yang dilakukan oleh ahli evaluasi untuk butir soal dan ahli media untuk komponen media yang telah dibuat, sedangkan pada validasi empiris yaitu validasi yang dilakukan secara langsung melalui analisis butir soal apda soal yang telah diujicobakan pada peserta didik.

Kelayakan butir soal pada media, penilian yang digunakan pada instruman penilaian ahli evaluasi yaitu Dhiah Fitrayati S.Pd., M.Pd., menggunakan Sudaryono (2012) dengan aspek yang dinilai yaitu materi, kontruksi dan Bahasa. Dari aspek materi indikator ke 4 pada instrumen penilaian yaitu mengukur kemampaun berpikir kritis siswa diketahui bahwa soal yang terdistribusi sesuai dengan indikator hanya berjumlah 12 butir soal selebihnya butir soal tidak terukur kemampuan berpikir kritis namun hanya sebatas C2-C3. Pada aspek kontruksi jumlah soal yang terdistribusi telah sesuai dengan indikator penilaian. Pada aspek kebahasaan jumlah yaitu penggunaan Bahasa yang baku, Bahasa yang komunikatif serta tidak menimbulan penafsiran ganda dengan jumlah soal yang terdistribusi telah sesuai dengan indikator penilaian. Rekaputulasi validasi butir soal oleh ahli evaluasi diperoleh hasil bahwa 20 butri soal yang disajikan dalam media telah sesuai dengan indikator pada angket penilaian oleh ahli evaluasi.

Selain itu, pada validasi secara empiris yaitu dengan dilakukannya analisis butir soal pada media yang telah diujicobakan. Pada analisis butir soal ini terdapat 4 macam yaitu taraf kesukaran, daya pembeda, validitas soal dan reliabilitas soal (Arikunto, 2013). Hasil dari analisis butir soal pada taraf kesukaran soal yaitu terdapat soal terdapat 12 soal dalam kategori "Sedang", sementara 6 soal berada pada kategori "Mudah" dan terdapat 2 butir soal yang termasuk dalam kategori "Sukar". Pada analisis daya pembeda terdapat 11 soal pada kategori "Sedang", sementara pada kategori "Baik" terdapat 4 soal dan pada kategori "Kurang Baik" terdapat 5 soal. Dan pada validitas soal rata-rata soal pada tingkat validitas cukup, sedangkan pada reliabilitas soal dapat disajikan sebagai berikut :

Gambar 3 Reliabilitas Soal

Reliability Statistics

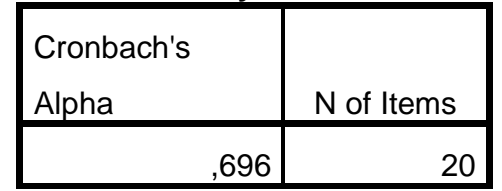

Sumber : Data diolah Peneliti (2019) 
Berdasarkan hasil uji, nilai Cronbach's Alpha sebesar 0,696 yang lebih besar daripada 0,6. Hal ini dapat dikatakan bahwa soal tersebut reliabel. Sehingga dari keseluruhan analisis butir soal yang dilakukan bahwa terdapat 14 dari 20 soal yang dapat dikatakan valid.

Pada kelayakan komponen pada media, penilaian yang digunakan pendapat dari Walker dan Hess (dalam Arsyad, 2014) melalui kualitas teknis dan kualitas instruksional dilakukan oleh ahli media Drs. Lamijan Hadi Susarno, M.Pd. hasil validasi penilaian kualitas teknis pada aspek keterbacaan sebesar $90 \%$ dikategorikan sangat layak. Pada aspek mudah digunakan persentase kelayakan sebesar $90 \%$ dikategorikan sangat layak. Kemudian pada aspek kualitas tampilan persentase kelayakan sebesar 92\% dikategorikan sangat layak. Pada aspek pengelolaan program diperoleh kelayakan sebesar $80 \%$ sehingga dikategorikan layak. Pada kualitas intruksional terdapat tiga aspek dengan empat indikator dengan persentase $100 \%$ dikategorikan sangat layak. Hasil rekapitulasi validasi media oleh ahli media pada kualitas teknis dan kualitas intruksioanl diperoleh persentase sebesar $92,2 \%$ sehingga dapat dikategorikan sangat layak sesuai dengan pendapat Riduwan (2016).

Hasil ini sesuai dengan penelitian Linda, Noer, \& Oktavianti (2016) yang menunjukkan bahwa ratarata hasil validasi media sebesar $95,63 \%$.

Dari hasil keseluruhan kelayakan pada media pembelajaran berbasis Lectora Inspire telah sesuai dengan indikator angket penilaian ahli media.

\section{Efektifitas Media}

Pada efektifitas media ini diperoleh melalui uji coba peserta didik dengan melihat ketuntasan hasil belajar serta peningkatan hasil belajar siswa. Dari hasil ketuntasan hasil belajar bahwa $85 \%$ siswa mendapatkan nilai $\geq 75$. Hal ini dapat dilihat dari hasil prestest menunjukkan bahwa jumlah siswa yang tuntas sebanyak $45 \%$ atau sebanyak 9 siswa. Tetapi setelah menggunakan media pembelajaran berbasis Lectora Inspire dan dilalukan posttest dengan hasil menunjukkan bahwa jumlah siswa yang tuntas sebanyak $85 \%$ atau sebanyak 17 siswa. Sehingga dapat disimpulkan bahwa hasil beljaar siswa setelah menggunakan media pembelajaran berbasis Lectora Inspire mengalami peningkatan sebesar $40 \%$. Sebelum diberikan media berbais Lectora Inspire siswayang tidak tuntas sebanyak 11 siswa dan setelah menggunakan media pembelajaran berbasis Lectora Inspire jumlah siswa yang tidak tuntas berkurang menjadi 3 siswa saja.
Sedangkan pada peningkatan siswa dalam berpikir kritis menggunakan gain score dengan ketentuan hasil belajar meningkat jika gain > 0,3 Hasil penelitian menunjukkan bahwa rata-rata hasil siswa dalam kategori tinggi, hanya terdapat tiga siswa yang masuk dalam kategori rendah. Sehingga dapat disimpulkan bahwa ketuntasan hasil belajar siswa lebih meningkat serta dapat kemampuan berpikir kritis siswa juga meningkat melalui media pembelajaran berbasis Lectora Inspire pada materi konsep badan usaha dalam perekonomian Indonesia.

Hasil ini sesuai dengan penelitian Marta, Simorangkir, Kariani, \& Sembiring (2018) yang berjudul "Effectiveness of Helped Mathematicial Learning Media of Lectora Inspire on The Number Sense Ability of Fifth Grade Students of Elementary School in Substrate Materials". Penelitian yang digunakan bahwa rata-rata peningakatan hasil belajar siswa yaitu 0,70 dengan kategori sangat tinggi.

Keefektitan media pembelajaran berbasis Lectora Inspire dikarenakan memiliki beberapa keunggulan diantaranya tampilan yang lebih menarik disesuaikan dengan konsep materi yang dipelajari, opsi jawaban soal yang dapat diacak sehingga mendorong siswa untuk belajar lebih rajin dan tidak tergantung pada temannya. Kemudian siswa dapat mengetahui skor hasil dari pengerjaan secara langsung.

\section{PENUTUP}

\section{Simpulan}

Kelayakan media pembelajaran berbasis Lectora Inspire dilakukan oleh dua ahli yaitu ahli evaluasi dan ahli media. Kelayakan ahli evaluasi menunjukkan bahwa butir soal yang disajikan pada media pembelajaran berbasis Lectora inspire telah sesuai dengan indikator pada instrumen penilaian. Sedangkan presentase hasil kelayakan media dari penilaian ahli media sebesar $92 \%$ menunjukkan dalam kategori sangat layak. Selain itu hasil dari efektivitas media pembelajaran berbasis Lectora Inspire dinyatakan efektif hal tersebut terbukti dengan adanya perbedaan nilai pretest dan posttest, dengan dibuktikan $85 \%$ nilai posttest siswa diatas kriteria ketuntasan minimal. Serta adanya peningkatan hasil belajar siswa dengan rata-rata gain score kriteria tinggi.

\section{Saran}

Perlunya perbaikan dalam pengembangan media untuk hasil yang lebih baik lagi dan dapat digunakan penyebaran yang lebih luas 


\section{DAFTAR PUSTAKA}

Abdullah, A. A., \& Suhartini. (2017). Meningkatkan Kemampuan Berpikir Kritis Melalui Pembelajaran Statistika Berbasis Pendidikan Politik Di Lingkungan Sekolah, II(1), 1-10.

Amri, S. (2015). Implementasi Pembelajaran Aktif dalam Kurikulum 2013. Jakarta: Prestasi Pustakaraya.

Arikunto, S. (2013). Dasar - Dasar Evaluasi Pendidikan. (R. Damyanti, Ed.) (edisi 2). Jakarta: PT. Bumi Aksara.

Arsyad, A. (2014). Media Pembelajaran. (A. Rahman, Ed.) (Edisi Revi). Jakarta: PT. RAJAGRAFINDO PERSADA.

Choy, S. C. (2009). Teacher Perceptions of Critical Thinking Among Students and its Influence on Higher Education Teacher Perceptions of Critical Thinking Among Students and its Influence on Higher Education. International Journal of Teaching And Learning in Higher Education, 20(2), 198-206.

Daryanto. (2016). Media Pembelajaran. Yogyakarta: Gava Media.

Linda, R., Noer, A. M., \& Oktavianti, N. A. (2016). Development of Lectora Inspire as Interactive Multimedia Chemistry Learning in Senior High School. Jurnal Pendidikan Kimia, 8(3), 188-196.

Marta, F., Simorangkir, A., Kariani, R., \& Sembiring, B. (2018). Effectiveness of Helped Mathematical Learning Media of Lectora Inspire on The Number Sense Ability of Fifth Grade Students of Elementary School in Substrate Materials, I(3), 352-358.

Morelent, Y. (2015). Pengaruh Penerapan Kurikulum 2013 Terhadap Pembentukan Karakter Siswa Sekolah Dasar Negeri 05 Percobaan Pintu Kabun Bukittinggi. Gramatika, 1(2), 141-152.

Muhli, A. (2011). Efektifitas Pembelajaran. Jakarta: Bumi Aksara.

OECD. (2015). PISA Results in Focus.

Sadiman, A. ., Raharjo, R., Haryono, A., \& Harjito. (2014). Media Pendidikan: Pengertian Pengembangan dan Pemanfaatannya. Jakarta: Raja Grafindo Persada.

Sari, D. S., \& Sugiyarto, K. H. (2015). Pengembangan Multimedia Berbasis Masalah Untuk Meningkatkan Motivasi Belajar Dan Kemampuan Berpikir Kritis Siswa. Jurnal Inovasi Pendidikan IPA, 1(2), 153166.

Sudaryono. (2012). Dasar - Dasar Evaluasi Pembelajaran. Yogyakarta: Graha Ilmu.

Sugiyono. (2016). Metodologi Penelitian Kuantitatif, Kualitatif, dan R\&D. Bandung: Alfabeta. 